\title{
Human tissue-type plasminogen activator
}

\author{
Production in continuous serum-free cell culture and rapid purification
}

\author{
Egbert K. O. KRUITHOF, Wolf-Dieter SCHLEUNING and Fedor BACHMANN \\ Laboratoire Central d'Hématologie, Centre Hospitalier Universitaire Vaudois, CH-1011 Lausanne, \\ Switzerland
}

(Received 24 June 1984/Accepted 15 November 1984)

\begin{abstract}
A simplified procedure for the production and purification of human tissue-type plasminogen activator ( $t-P A)$ is described. Bowes-melanoma cells were maintained in continuous serum-free culture. The cell nutrient consisted of Dulbecco's modified Eagle's medium (DMEM) supplemented with insulin $(5 \mathrm{mg} / \mathrm{litre})$, transferrin $(5 \mathrm{mg} /$ litre), progesterone ( $1 \mathrm{nM})$, cortisol ( $10 \mathrm{nM})$, aprotinin $\left(2 \times 10^{4}\right.$ units/litre) and a mixture of trace elements. t-PA accumulated in the culture medium at a rate of 40 units/day per $\mathrm{ml}$ and was harvested every third day. Cell losses during each harvest, leading to a steady decline of enzyme yields, were compensated for by treating the cells with $5 \%(\mathrm{v} / \mathrm{v})$ fetal-bovine serum in DMEM every 6-8 weeks. t-PA was rapidly purified by a combination of cation-exchange chromatography and gel filtration. The procedure yielded mainly single-chain t-PA of a specific activity of 80000 to 100000 units/mg.
\end{abstract}

Thrombolysis as a therapeutic approach to remove enzymically blood clots in the vascular system has recently gained renewed interest. Thromboembolic events are a common cause of life-threatening diseases such as pulmonary embolism, acute myocardial infarction and stroke. Suitable thrombolytic agents activate the plasma zymogen plasminogen to plasmin (EC 3.4.21.7), a potent fibrin-degrading enzyme. Human tissuetype plasminogen activator (t-PA) achieves thrombolysis without concomitant systemic alterations in fibrinogen and $\alpha_{2}$-antiplasmin levels (Matsuo et al., 1981; Korninger et al., 1982). Thus the dangerous bleeding tendency induced by streptokinase or urokinase may be avoided. The scarcity of t-PA has limited the scale of controlled clinical studies. Therefore progress in this field is dependent on the development of economical methods for the production of $t$-PA.

Below we report conditions for the production of

Abbreviations used: DMEM, Dulbecco's modified Eagle's medium; SDS, sodium dodecyl sulphate; t-PA, tissue-type plasminogen activator; FBS, fetal-bovine serum; SP-Sephadex, sulphopropyl-Sephadex; SF medium, serum-free medium (see the text for full composition); phosphate-buffered saline, $\mathrm{pH} 7.3$ buffer of composition (g/litre): $\mathrm{NaCl}, 8 ; \mathrm{KCl}, 0.2 ; \mathrm{Na}_{2} \mathrm{HPO}_{4}$, $2 \mathrm{H}_{2} \mathrm{O}$ ), 1.44; $\mathrm{KH}_{2} \mathrm{PO}_{4}, 0.2$.
t-PA in continuous serum-free cell culture and a simple rapid purification procedure.

\section{Experimental}

\section{Materials}

Dextran (Macrodex), protein A-Sepharose, SPSephadex and $M_{\mathrm{r}}$-marker proteins phosphorylase $b(94000)$, bovine serum albumin (67000), ovalbumin (43000) and carbonic anhydrase (30000) were from Pharmacia, Uppsala, Sweden; fibrinogen (bovine) from Poviet, Oss, The Netherlands; thrombin (Topostasin) from HoffmannLaRoche, Basel, Switzerland; insulin and transferrin from Calbiochem, La Jolla, CA, U.S.A.; progesterone (Lutocyclin) from Ciba-Geigy, Basel, Switzerland; cortisol (Solu-Cortef) from Upjohn, Puurs, Belgium; aprotinin (Trasylol) from Bayer, Leverkusen, Germany; the Immun-Blot assay kit and all reagents for SDS/polyacrylamidegel electrophoresis from Bio-Rad, Richmond, CA, U.S.A.; tissue-culture flasks from Corning Glass Works, Corning, NY, U.S.A., and the cell factories (Multitray Units, $335 \mathrm{~mm} \times 205 \mathrm{~mm} \times$ $190 \mathrm{~mm}$ ) from Nunc, Roskilde, Denmark. Bowesmelanoma cells were obtained from Professor Daniel B. Rifkin, Department of Cell Biology, New York University, NY, U.S.A. 


\section{Assay of $t-P A$ activity}

A $30 \mu 1$ portion of a suitably diluted sample was added to $0.25 \mathrm{ml}$ of a solution containing fibrinogen $(1.5 \mathrm{mg} / \mathrm{ml})$, plasminogen $(50 \mu \mathrm{g} / \mathrm{ml})$ and dex$\operatorname{tran}(15 \mathrm{mg} / \mathrm{ml})$ in $0.15 \mathrm{M}$-Tris $/ \mathrm{HCl}$, $\mathrm{pH} 7.8$, prewarmed to $37^{\circ} \mathrm{C}$. After $1 \mathrm{~min}, 50 \mu 1$ of thrombin $(10$ units $/ \mathrm{ml}$ ) were added. The lysis times (interval between addition of the thrombin and complete lysis of the clot) were compared with those obtained by using a laboratory-standard t-PA preparation [1 unit $/ \mathrm{ml}$ corresponds to a t-PA concentration of $10 \mathrm{ng} / \mathrm{ml}$ ]. [In June 1984, the Expert Committee of Biological Standardization of the World Health Organisation established an International Standard for human t-PA. Comparison with our laboratory standard t-PA preparation revealed that one of our units corresponds to $3.4 \mathrm{i}$.u. when assayed on a conventional fibrin plate]. t-PA concentrations between 25 and 200 units/ml yielded lysis times between 20 and $7 \mathrm{~min}$ and correlated with the reciprocal of lysis time squared. Protein was quantified by the method of Bradford (1976), with bovine serum albumin as a standard. Protein determinations in culture supernatant were made with albumin standards in DMEM.

\section{Cell culture}

Bowes-melanoma cells (Rifkin et al., 1974) were cultured in DMEM supplemented with $5 \%$ FBS or with insulin $(5 \mathrm{mg} /$ litre), transferrin $(5 \mathrm{mg} / \mathrm{litre})$, progesterone ( $1 \mathrm{nM})$, cortisol (10nM) (Mather \& Sato, 1979), aprotinin $\left(2 \times 10^{4}\right.$ units/litre $)$ and a mixture of trace elements (Hutchins \& Sato; 1978) (SF medium).

\section{Antibodies against human $t-P A$}

Human t-PA was purified from the conditioned media of 12-O-tetradecanoyl phorbol-13-acetate stimulated $\mathrm{HeLa}$ cells and injected into rabbits for the generation of antibodies. IgG was isolated by affinity chromatography on protein A-Sepharose. It precipitated a single $\left[{ }^{35} \mathrm{~S}\right]$ methionine-labelled protein from conditioned medium of HeLa cells or of Bowes-melanoma cells (Fig. 1). Details of these procedures will be described elsewhere (Waller \& Schleuning, 1985).

\section{Electrophoretic procedures}

SDS/polyacrylamide-gel electrophoresis (Laemmli, 1970) was performed in a $12 \%(w / v)$ gel. Proteins were electroblotted from the gels to nitrocellulose and revealed by immunochemical staining (Towbin et al., 1979) using rabbit anti(human t-PA) IgG followed by goat anti-rabbit IgG-horseradish peroxidase conjugate provided with the Bio-Rad Immun-Blot assay kit.

Electrophoretic-zymographic analysis of t-PA

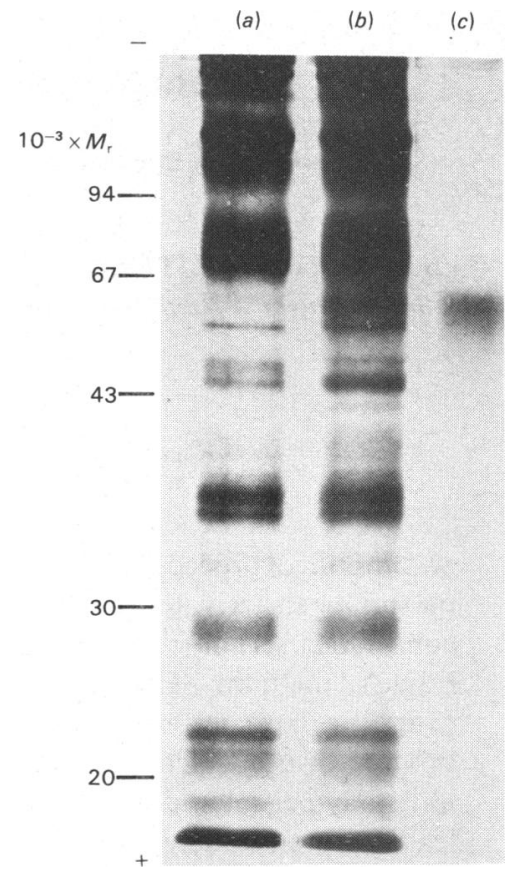

Fig. 1. Characterization of anti-t-PA antibody specificity A $5 \mathrm{ml}$ portion of metabolically $\left.{ }^{35} \mathrm{~S}\right]$ methioninelabelled conditioned medium of Bowes-melanoma cells was passed over a $1 \mathrm{ml}$ column of anti-t-PA IgG immobilized on CNBr-activated Sepharose 4B. After washing the column with $100 \mathrm{ml}$ of phosphatebuffered saline containing $0.5 \mathrm{M}-\mathrm{NaCl} / 0.002 \mathrm{M}$ EDTA $/ 0.1 \%$ Tween 80 and $0.01 \%$ SDS, $t$-PA was eluted with phosphate-buffered saline/3 $\mathrm{M}-\mathrm{NaSCN}$, containing horse myoglobin $(200 \mu \mathrm{g} / \mathrm{ml})$ to prevent adsorptive losses of t-PA. Lanes $(a)$ and $(b)$ represent the labelled conditioned medium after $(a)$ and before $(b)$ passage through anti-t-PA IgG-Sepharose. After dialysis, the immune eluate contained 600 t-PA units of plasminogen activator activity $/ \mathrm{ml}$; it moved as a single band of $M_{\mathrm{r}} \mathbf{6 7 0 0 0}$ on SDS/polyacrylamide-gel electrophoresis (lane $c$ ).

on fibrin-agarose underlays was done by the method of Granelli-Piperno \& Reich (1978) as modified by Tissot et al. (1982).

\section{Results}

Preliminary experiments had shown that melanoma cells were well maintained in SF medium, but that their growth rate was extremely slow. Therefore, for large-scale production of t-PA, melanoma cells were first grown to confluency in DME containing $5 \%$ FBS in $6000 \mathrm{~cm}^{2}$ Nunc cell factories. After the cells reached confluency, the factories were washed twice with phosphatebuffered saline (1 litre per factory) and incubated 


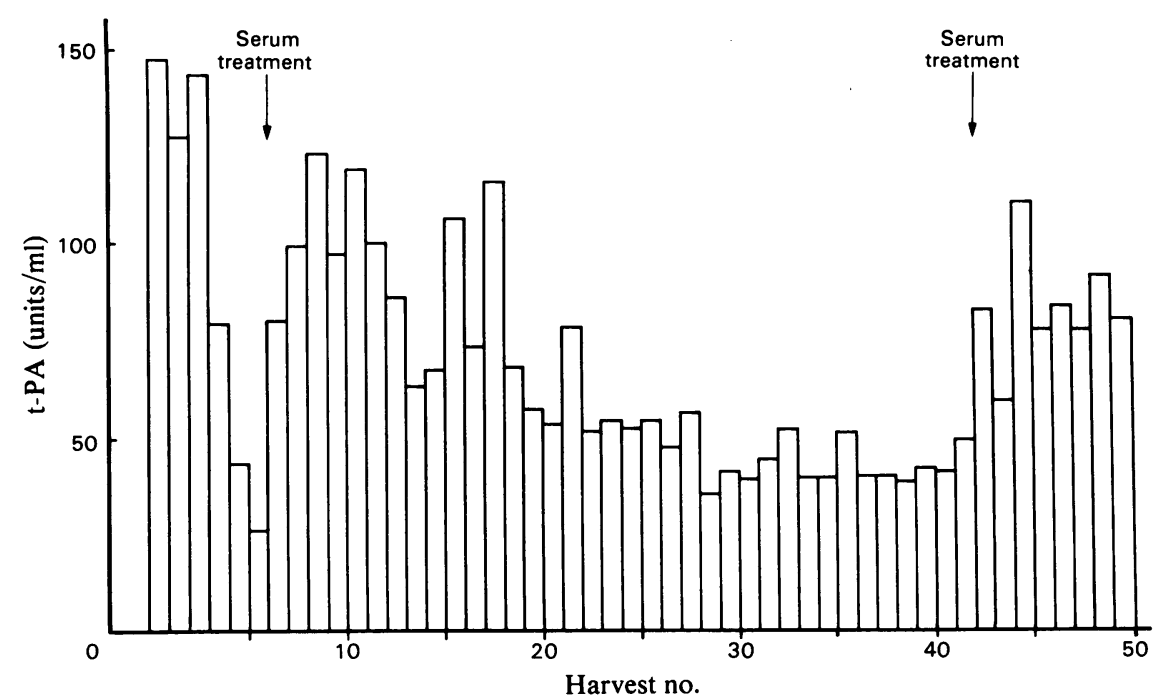

Fig. 2. Large-scale continuous production of $t-P A$ in $S F$ medium

Melanoma cells were grown to confluency in four cell factories in DMEM $+5 \% \mathrm{FBS}$, twice washed with phosphatebuffered saline and incubated for $6 \mathrm{~h}$ in DMEM. Each factory was then filled with 1 litre of SF medium which was replaced every 3-4 days. At the times indicated by arrows, the cells were treated for 2 days with DMEM $+5 \% \mathrm{FBS}$, twice washed with phosphate-buffered saline, incubated for $6 \mathrm{~h}$ in DMEM and again cultivated in SF medium.

for $6 \mathrm{~h}$ in DMEM alone to remove the bulk of the serum proteins. The cells were then further incubated in SF medium (1 litre/factory). The medium was replaced every 3-4 days. Fig. 2 shows t-PA activity in the conditioned medium for 50 subsequent harvests. t-PA activities tended to decline with time owing to losses of cells from the factory, but could be restored by a 3-day treatment of the cells with DMEM $+5 \%$ FBS. With interruption by serum treatment every 6-8 weeks, the same production rate could be maintained for over 8 months.

\section{Purification of $t-P A$}

The conditioned medium was centrifuged at $20^{\circ} \mathrm{C}$ and $2000 \mathrm{~g}$ for $10 \mathrm{~min}$. Tween $80(0.01 \%)$ and $\mathrm{NaN}_{3}(0.1 \%)$ were added to the supernatant. This was stored at $4^{\circ} \mathrm{C}$ for up to 4 days. The $\mathrm{pH}$ was adjusted to 4.5 by dropwise addition of $6 \mathrm{M}-\mathrm{HCl}$. A fine precipitate was removed by centrifugation $\left(30 \mathrm{~min}, 4^{\circ} \mathrm{C}, 4000 \mathrm{~g}\right)$. Fig. 3 demonstrates the ionexchange purification step with SP-Sephadex at $\mathrm{pH}$ 4.5. Most of the contaminating proteins passed unadsorbed through the column (result not shown). As judged from activity measurements in the runthrough fractions, t-PA bound quantitatively to the gel. Eluate fractions with activities above 1000 units $/ \mathrm{ml}$ were pooled, concentrated to $7 \mathrm{ml}$ in an Amicon stirred cell with a YM 30 membrane, and passed over a $600 \mathrm{ml}$ column of Sephadex G-100

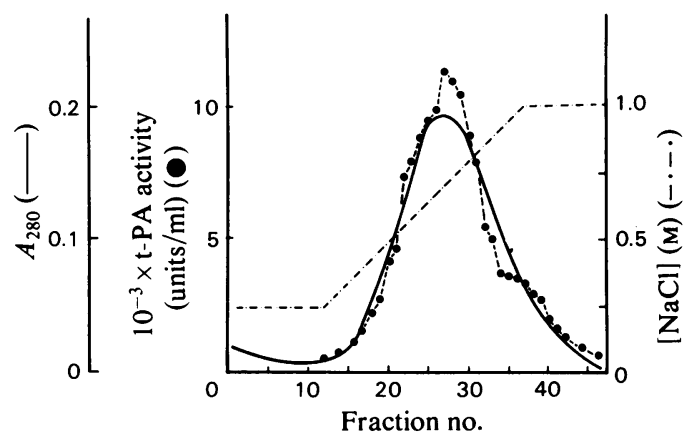

Fig. 3. Purification of human t-PA on SP-Sephadex Melanoma culture supernatant (6.5 litres) was adjusted to $\mathrm{pH} 4.5$ and passed at a rate of $500 \mathrm{ml} / \mathrm{h}$ over a $3.2 \mathrm{~cm} \times 10 \mathrm{~cm}(80 \mathrm{ml}) \mathrm{SP}$-Sephadex column previously equilibrated with $0.1 \mathrm{M}$-sodium acetate/ $0.25 \mathrm{M}-\mathrm{NaCl} / 0.01 \%$ Tween $80 / 0.05 \% \mathrm{NaN}_{3}, \mathrm{pH} 4.5$. The run-through fractions contained about $280 \mathrm{mg}$ of protein (not shown), but less than $1 \%$ of total activity. After washing of the column with $150 \mathrm{ml}$ of the same buffer, t-PA was eluted by a $\mathrm{NaCl}$ gradient from 0.25 to $1 \mathrm{M}$ in the same buffer. The activity of $6 \mathrm{ml}$ fractions was measured by using the fibrin-clotlysis assay (O). The concentration of $\mathrm{NaCl}$ was determined with a conductivity meter $(-\cdot-) ; A_{280}$ (-) was also measured.

(Fig. 4). t-PA activity was almost quantitatively eluted with the second protein peak. Fractions with activities above 1000 units $/ \mathrm{ml}$ were com- 


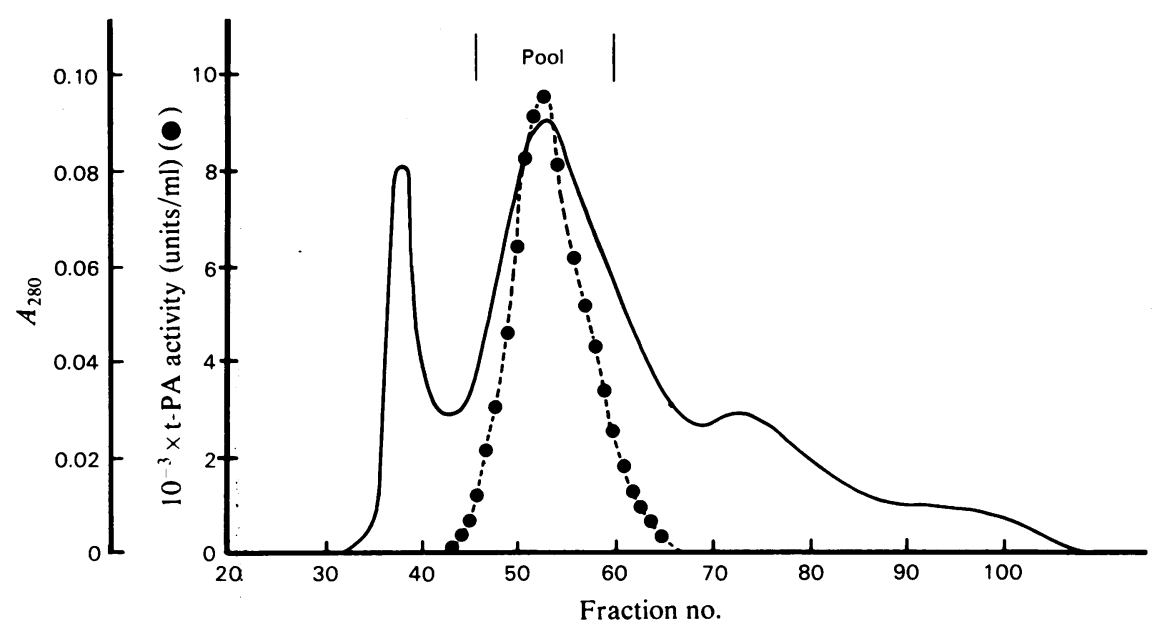

Fig. 4. Purification of human $t-P A$ on Sephadex $G-100$

Peak activity fractions $(80 \mathrm{ml})$ of the SP-Sephadex step were pooled, concentrated to $7 \mathrm{ml}$ by ultrafiltration and passed over a $3.2 \mathrm{~cm} \times 75 \mathrm{~cm}(600 \mathrm{ml})$ Sephadex G-100 column in $50 \mathrm{~mm}$-sodium acetate $/ 0.5 \mathrm{M}-\mathrm{NaCl} / 0.01 \% \mathrm{Tween}$ $80 / 0.05 \% \mathrm{NaN}_{3}, \mathrm{pH} 4.5$. The activity of $5 \mathrm{ml}$ fractions was measured by using the fibrin-clot-lysis assay (O); $A_{280}$ $(\longrightarrow)$ was also measured.

Table 1. Purification of human t-PA from melanoma culture supernatant

$\begin{array}{lccccccr} & \begin{array}{c}\text { Volume } \\ (\mathrm{ml})\end{array} & \begin{array}{c}\text { [Protein] } \\ (\mathrm{mg} / \mathrm{ml})\end{array} & \begin{array}{c}\text { Activity } \\ \text { (units/ml) }\end{array} & \begin{array}{c}\text { Total } \\ \text { activity } \\ \text { (units) }\end{array} & \begin{array}{c}\text { Specific } \\ \text { activity } \\ \text { (units/mg) }\end{array} & \begin{array}{c}\text { Purification } \\ \text { factor }\end{array} & \begin{array}{r}\text { Yield } \\ (\%)\end{array} \\ \begin{array}{l}\text { Culture supernatant } \\ \begin{array}{l}\text { SP-Sephadex after } \\ \text { concentration }\end{array}\end{array} & 6500 & 0.045 & 71 & 460000 & 1600 & 1 & 100 \\ \begin{array}{l}\text { Sephadex G-100 after } \\ \text { concentration }\end{array} & 7 & 0.93 & 42800 & 300000 & 46000 & 29 & 65 \\ & 8 & 0.38 & 35000 & 280000 & 92000 & 58 & 61\end{array}$

bined, concentrated by ultrafiltration in the stirred cell and stored at $-70^{\circ} \mathrm{C}$. This preparation had a specific activity between 80000 and 100000 units/ mg (Table 1).

\section{Characterization of purified $\boldsymbol{t}-\boldsymbol{P A}$}

The purified material contained mainly singlechain t-PA. This is illustrated in Fig. 5. Protein staining of non-reduced (lane 1) or reduced (lane 2) samples as well as immunoblotting of non-reduced (lane 3) or reduced (lane 4) material, and zymographic detection of plasminogen activator activity on plasminogen-rich fibrin-agarose underlays consistently revealed a major band in the 60000 $67000-M_{\mathrm{r}}$ region. The $M_{\mathrm{r}}$ obtained for reduced t-PA was about 67000 , a value which is similar to that found by others (Rijken \& Collen, 1981; Wallén et al., 1983). In reduced samples, several additional bands were seen on stained gels, most of which reacted with anti-t-PA IgG as revealed by immunoblotting. The doublet in the $60000-M_{\mathrm{r}}$ region (lanes 2 and 4) corresponds to a slightly degraded single-chain t-PA (Bányai et al., 1983) exhibiting also some fibrinolytic activity (lane 5); the bands in the $35000-38000-M_{\mathrm{r}}$ region correspond to variably glycosylated forms of the Achain (reviewed by Bachmann \& Kruithof, 1984), and the $32000-M_{\mathrm{r}}$ form is attributable to the Bchain of double-chain t-PA. Lanes 2 and 4 demonstrate that one further minor band of $M_{\mathrm{r}}$ 24000 is t-PA-related. Another minor band of $M_{\mathrm{r}}$ 31000 apparently represents a contaminating protein, since it was only present on stained gels.

\section{Discussion}

In animal models of thrombosis and myocardial infarction, $t$-PA was shown to be a thrombolytic agent superior to urokinase and streptokinase 


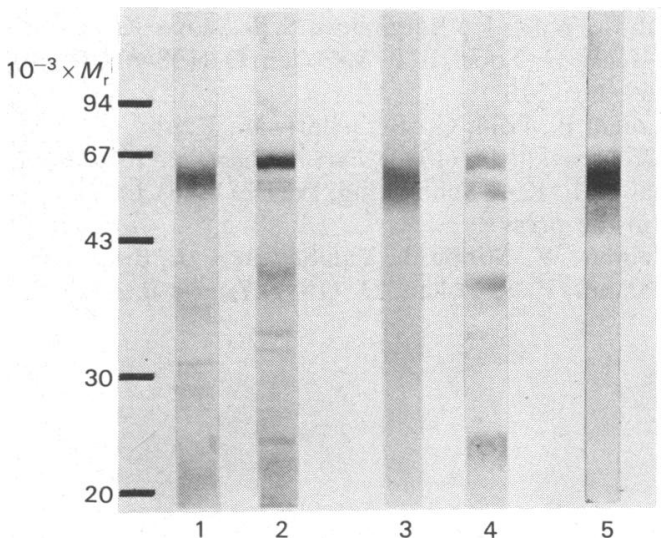

Fig. 5. Electrophoretic analysis of purified human $t-P A$ SDS/polyacrylamide-gel-electrophoretic patterns in a $12 \%(w / v)$ gel. 1 and 2, Coomassie Brilliant Bluestained gels of $20 \mu \mathrm{g}$ of non-reduced (1) and reduced (2) t-PA; 3 and 4 , peroxidase-stained bands of $1 \mu \mathrm{g}$ of non-reduced (3) and reduced (4) t-PA, electrophoretically transferred after SDS/polyacrylamidegel electrophoresis to nitrocellulose and incubated with rabbit anti-t-PA antibodies followed by goat anti-rabbit IgG-horseradish peroxidase conjugate; 5 , zymographic analysis of $2.5 \mu \mathrm{g}$ of purified nonreduced $t$-PA after $3 \mathrm{~h}$ incubation on a fibrinagarose underlay.

(Korninger et al., 1982; Mattsson et al., 1983; Collen et al., 1983; Bergmann et al., 1983). In man, thrombolytic therapy with t-PA has been successful (Weimar et al., 1981; Van de Werf et al., 1984a). Therefore production of large quantities of t-PA at reasonable cost is desirable. t-PA has been previously purified from the culture supernatant of Bowes-melanoma cells (Rijken \& Collen, 1981; Wallén et al., 1983). The large-scale production and purification of t-PA by the described methods, however, is costly and time-consuming. The production of t-PA by recombinant-DNA technology (Pennica et al., 1983; Edlund et al., 1983) may make available large quantities of t-PA in the near future, but it remains to be established whether $t$-PA produced in bacteria or yeast exhibits the same behaviour in vivo as native t-PA. The production of t-PA by recombinant-DNA technology in mammalian cells (Van de Werf et al., 1984b) after gene transfection and amplification is advantageous in terms of enzyme yields, but the cells have to be cultivated in the presence of serum. This increases media costs and renders purification more difficult. The continuous production of t-PA by melanoma cells in serum-free medium described here greatly reduces the investment of labour and the cost of media. Compared with the supplements recommended by Hutchins \& Sato (1978) and Mather \& Sato (1979), we restricted the number of hormones to the minimum necessary for maintaining t-PA production. Some cell losses, however, occurred during media changes, which made it necessary to treat the cells every 6-8 weeks with serum containing medium to restore the original cell density. The absence of serum-derived proteins greatly facilitated the purification of t-PA from the conditioned medium. The simple twostep purification procedure is reproducible and can easily be scaled up. The final product consisted mainly of single-chain t-PA, but minor quantities of a slightly degraded single-chain form of t-PA (Bányai et al., 1983) and of double-chain t-PA were present.

This work was supported by grants nos. 3.688-0.80 and 3.461-0.83 from the Swiss National Fund for Scientific Research. We thank Mrs. E. Bachmann for technical assistance, and Mrs. J. Guillemin and Mrs. J. Rochat for typing the manuscript.

\section{References}

Bachmann, F. \& Kruithof, E. K. O. (1984) Semin. Thromb. Hemostasis 10, 6-17

Bányai, L., Váradi, A. \& Patthy, L. (1983) FEBS Lett. 163, 37-41

Bergmann, S. R., Fox, K. A. A., Ter-Pogossian, M. M., Sobel, B. E. \& Collen, D. (1983) Science 220, 1181 1183

Bradford, M. M. (1976) Anal. Biochem. 72, 248-254

Collen, D., Stassen, J. M. \& Verstraete, M. (1983) J. Clin. Invest. 71, 368-376

Edlund, T., Ny, T., Rånby, M., Hedén, L.-O., Palm, G., Holmgren, E. \& Josephson, S. (1983) Proc. Natl. Acad. Sci. U.S.A. 80, 349-352

Granelli-Piperno, A. \& Reich, E. (1978) J. Exp. Med. 148, 223-234

Hutchins, S. E. \& Sato, G. H. (1978) Proc. Natl. Acad. Sci. U.S.A. 75, 901-904

Korninger, C., Matsuo, O., Suy, R., Stassen, J. M. \& Collen, D. (1982) J. Clin. Invest. 69, 573-580

Laemmli, U. K. (1970) Nature (London) 227, 680-685

Mather, J. P. \& Sato, G. H. (1979) Exp. Cell. Res. 120 , 191-200

Matsuo, O., Rijken, D. C. \& Collen, D. (1981) Nature (London) 291, 590-591

Mattsson, Ch., Nilsson, S. \& Häggroth, L. (1983) Thromb. Res. 30, 91-100

Pennica, D., Holmes, W. E., Kohr, W. J., Harkins, R. N., Vehar, G. A., Ward, C. A., Bennett, W. F., Yelverton, E., Seeburg, P. H., Heyneker, H. L., Goeddel, D. V. \& Collen, D. (1983) Nature (London) 301, 214-221

Rifkin, D. B., Loeb, J. N., Moore, G. \& Reich, E. (1974) J. Exp. Med. 139, 1317-1328

Rijken, D. C. \& Collen, D. (1981) J. Biol. Chem. 256, 7035-7041 
Tissot, J.-D., Schneider, Ph., Hauert, J., Ruegg, M., Kruithof, E. K. O. \& Bachmann, F. (1982) J. Clin. Invest. 70, 1320-1323

Towbin, H., Staehelin, T. \& Gordon, J. (1979) Proc. Natl. Acad. Sci. U.S.A. 76, 4350-4354

Van de Werf, F., Ludbrook, P. A., Bergmann, S. R., Tiefenbrunn, A. J., Fox, K. A. A., de Geest, M., Verstraete, M., Collen, D. \& Sobel, B. E. (1984a) New Engl. J. Med. 310, 609-613
Van de Werf, F., Bergmann, S. R., Fox, K. A. A., de Geest, H., Sobel, B. E. \& Collen, D. (1984b) Circulation 69, 605-610

Wallén, P., Pohl, G., Bergsdorf, N., Rånby, M., Ny, T. \& Jörnvall, H. (1983) Eur. J. Biochem. 132, 681-686

Waller, E. K. \& Schleuning, W. D. (1985) J. Biol. Chem. in the press

Weimar, W., Stibbe, J., Van Seyen, A. J., Billiau, A., de Somer, P. \& Collen, D. (1981) Lancet ii, 1018-1020 